PYTHAGORAS: Jurnal Pendidikan Matematika

Volume 11 - Nomor 1, Juni 2016, (102-110)

Available online at: http://journal.uny.ac.id/index.php/pythagoras

\title{
Pengaruh Pembelajaran Bangun Ruang Sisi Lengkung Melalui CTL dan Open Ended terhadap Hasil Belajar Kognitif, Sikap, dan Keterampilan
}

\author{
Y. Yamti \\ SMP Negeri 9 Yogyakarta, Jalan Ngeksigondo No.30, Yogyakarta, 55172, Indonesia \\ Korespondensi Penulis. Email: yamti_smp9@yahoo.com, Telp: +628122762274 \\ Received: 15 $5^{\text {th }}$ June 2016; Revised: 30 ${ }^{\text {th }}$ June 2016; Accepted: $1^{\text {st }}$ September 2016
}

\begin{abstract}
Abstrak
Tujuan penelitian ini adalah untuk menemukan (1) pengaruh pembelajaran pada bangun ruang sisi lengkung dengan strategi pembelajaran kooperatif Contextual Teaching and Learning (CTL) dan Open Ended terhadap hasil belajar kognitif siswa, (2) pengaruh pembelajaran pada bangun ruang sisi lengkung dengan strategi pembelajaran kooperatif CTL dan Open Ended terhadap sikap siswa, dan (3) pengaruh pembelajaran pada bangun ruang sisi lengkung dengan strategi pembelajaran kooperatif $C T L$ dan Open Ended terhadap keterampilan matematika siswa. Jenis penelitian adalah eksperimen semu. Populasi penelitian adalah seluruh siswa kelas IX SMP Muhammadiyah 8 Yogyakarta tahun pelajaran 2014/2015, sedangkan sampel penelitian adalah siswa kelas IX D dipilih secara acak. Hasil penelitian menunjukkan bahwa terdapat pengaruh pembelajaran bangun ruang sisi lengkung dengan strategi kooperatif CTL dan Open Ended terhadap hasil belajar kognitif, sikap, dan keterampilan siswa.
\end{abstract}

Kata Kunci: contextual teaching and learning, open ended, hasil belajar kognitif, hasil belajar sikap, hasil belajar keterampilan

\section{The Influence of the Space Curved Side Up Learning Through CTL and Open Ended toward the Learning Result of Cognitive, Attitude, and Skill}

\begin{abstract}
The aims of this research was to investigate: (1) the influence of the space curved side up learning with CTL cooperative learning strategy and Open Ended toward the students learning result of cognitive, (2) the influence of the space curved side up learning with CTL cooperative learning strategy and Open Ended toward the students learning result of attitude, and (3) the influence of the space curved side up learning with CTL cooperative learning strategy and Open Ended toward the students learning result of mathematical skills. This research was quasi experiment. The population of research was all students grade IX SMP Muhammadiyah 8 Yogyakarta, while the sample of research was students in class IX D selected randomly. The results show that the space curved side up learning with the of contextual teaching learning and open ended has influence toward the students learning result of cognitive, attitude, and skills.
\end{abstract}

Keywords: contextual teaching and learning, open ended, the learning result of cognitive, the learning result of attitude, the learning result of skills.

How to Cite: Yamti, Y. (2016). Pengaruh pembelajaran bangun ruang sisi lengkung melalui CTL dan open ended terhadap hasil belajar kognitif, sikap, dan keterampilan. PYTHAGORAS: Jurnal Pendidikan Matematika, 11(1), 102-110. doi:http://dx.doi.org/10.21831/pg.v11i1.9677

Permalink/DOI: http://dx.doi.org/10.21831/pg.v11i1.9677 


\section{PENDAHULUAN}

Salah satu tujuan utama dari pendidikan adalah meningkatkan kualitas sumber daya manusia. Tujuan pendidikan di Indonesia menurut Undang-undang Nomor 20 Tahun 2003 tentang Sistem Pendidikan Nasional Pasal 1 ayat 1 menyatakan bahwa "pendidikan adalah usaha sadar dan terencana untuk mewujudkan suasana belajar dan proses pembelajaran agar peserta didik secara aktif mengembangkan potensi dirinya untuk memiliki kekuatan spiritual keagamaan, pengendalian diri, kepribadian, kecerdasan, akhlak mulia, serta keterampilan yang diperlukan dirinya, masyarakat, bangsa dan negara".

Pendidikan tidak terlepas dari kegiatan belajar. Belajar merupakan kegiatan aktif dari peserta didik untuk membangun makna dan pengetahuan yang dilakukan sendiri atau bersama orang lain, dapat mendiskripsikan perubahan potensi perilaku yang berasal dari pengalaman (Arend \& Kilcher, 2010, p.381). Menurut Ambrose (2010, p.3) terdapat tiga komponen penting dalam definisi belajar, yakni "(1) learning is a process, not a product; (2) learning involves change in knowledge, beliefs, behaviors, or attitudes. This change unfolds over time; it is not fleeting but rather has a lasting impact on how students think and act; (3) learning is not something done to students, but rather something students themselves do". Berdasarkan pendapat tersebut, dapat diketahui bahwa (1) belajar adalah sebuah proses, bukan produk, (2) belajar melibatkan perubahan dalam pengetahuan, kepercayaan, perilaku, atau sikap, dimana perubahan perilaku ini relatif tetap, tidak cepat berganti dan memiliki dampak yang tetap pada bagaimana siswa berpikir dan bertindak, (3) belajar bukan sesuatu yang dilakukan kepada siswa, melainkan bagaimana siswa itu sendiri yang melakukannya. Senada dengan pendapat tersebut, Nitko \& Brookhart (2011, p.18) dan Trianto (2009, p.17) mengemukakan bahwa pembelajaran adalah proses yang digunakan untuk menyiapkan siswa dengan kondisi yang membantu mereka mencapai target pembelajaran. Beberapa target pembelajaran adalah kognitif yang berarti bahwa ide dasar dengan pengetahuan intelektual dan keterampilan berpikir.

Keberhasilan dari kegiatan belajar dapat diukur dengan penilaian hasil belajar. Penilaian hasil belajar menurut Rusman (2014, p.276) adalah proses pemberian nilai terhadap hasilhasil belajar yang dicapai dengan menggunakan kriteria tertentu. Hasil belajar tersebut hakekatnya merupakan kompetensi-kompetensi yang mencakup aspek pengetahuan, keterampilan, sikap, dan nilai-nilai yang diwujudkan dalam kebiasaan berpikir dan bertindak. Proses kognitif dalam pembelajaran menurut Anderson \& Krathwohl (Widoyoko, 2014, p.30) dibagi menjadi enam jenjang mulai dari jenjang yang paling rendah ke jenjang yang paling tinggi, yaitu mengingat, memahami, mengaplikasikan, menganalisis, mengevaluasi dan mencipta (remember, understand, apply, analyze, evaluate, dan create).

Salah satu produk belajar adalah sikap. Sikap adalah proses mental yang berkaitan dengan kecenderungan seseorang memilih ketika berhadapan dengan alternatif-alternatif. Jika seseorang memiliki kecerdasan untuk memilih sesuatu yang baik, maka dia memiliki sikap positif. Begitu pula jika memilih sesuatu yang buruk maka dikatakan memiliki sikap negatif (Nitko \& Brookhart, 2007, p.451).

Menurut Nitko \& Brookhart (2007: p.451) menyatakan bahwa "attitudes are characteristic of person that discribe their positive and negative feelings toward particular objects, sitiations, institutions, persons, or ideas". Sikap adalah karakteristik dari seseorang yang menggambarkan perasaan positif (suka) dan negatif (tidak suka) terhadap objek, situasi, institusi, seseorang atau ide tertentu. Sedangkan menurut Olatunde (Rahmawati \& Harta, 2014, p.115), bahwa sikap siswa terhadap matematika dipengaruhi oleh guru dan metode pembelajaran yang diterapkan. Kedua hal ini besar sekali peranannya, sehingga bisa terlihat seberapa besar sikap siswa terhadap hasil belajar. Menurut Zan \& Martino (2007, p.158) "attitude toward mathematics and emotions with mathematics", maksudnya adalah sikap siswa terhadap matematika dapat dilihat sebagai pola dari keyakinan dan emosi mereka terhadap matematika. Selain itu menurutnya, pilihan dengan persetujuan pada keyakinan tertentu untuk menentukan suatu jawaban atas pertanyaan reaksi emosional (suka atau tidak suka) dapat dihubungkan dengan pandangan terhadap matematika.

Salah satu produk belajar yang lain adalah keterampilan. Keterampilan menunjukkan tingkat keahlian seseorang dalam melaksanakan tugas atau sekumpulan tugas tertentu. Keterampilan atau psikomotor merupakan kemampuan bertindak setelah seseorang menerima pengalaman belajar tertentu. Widoyoko (2014, p.46), Leighbody (Majid, 2014, p.53) berpendapat 
bahwa penilaian hasil belajar psikomotor mencakup: (1) kemampuan menggunakan alat dan sikap kerja; (2) kemampuan menganalisis suatu pekerjaan dan menyusun urut-urutan pekerjaan; (3) kecepatan mengerjakan tugas; (4) kemampuan membaca gambar dan atau simbol; (5) keserasian bentuk dengan yang diharapkan dan atau ukuran yang telah ditentukan. Penilaian hasil belajar psikomotor atau keterampilan harus mencakup persiapan, proses, dan produk. Penilaian dapat dilakukan pada saat proses berlangsung yaitu pada waktu peserta didik melakukan praktik, atau sesudah proses berlangsung dengan cara mengetes peserta didik. Penilaian psikomotorik dapat dilakukan dengan menggunakan observasi atau pengamatan.

Terdapat berbagai strategi pembelajaran yang bisa digunakan dalam proses belajar dan mengajar. Kedua strategi pembelajaran yang dijadikan topik dapam penelitian ini adalah CTL dan open ended. Putri \& Abadi (2014) mengemukakan bahwa CTL efektif ditinjau dari ketercapaian SK/KD dalam pembelajaran matematika. Johnson (2002, p.17) berpendapat bahwa "CTL is a system that stimulates the brain to weave patterns that express meaning. CTL is a brain-compatible system of instruction that generates meaning by linking academic content with the context of a student's daily life". Dari definisi tersebut yang mengatakan bahwa sebuah sistem yang merangsang otak untuk menyusun pola-pola yang mewujudkan makna, dan mendefinisikan CTL sebagai suatu sistem pengajaran yang cocok dengan otak karena menghasilkan makna dengan menghubungkan muatan akademis dengan konteks dari kehidupan sehari-hari siswa. Rusman (2010, pp.193-198) mengemukakan bahwa terdapat tujuh prinsip pembelajaran CTL yang harus dikembangkan oleh guru yaitu (1) konstruktivisme yang merupakan landasan pikiran filosofi dalam CTL yang menyatakan bahwa pengetahuan dibangun oleh manusia sedikit demi sedikit, yang hasilnya diperluas melalui konteks yang terbatas; (2) menemukan (inquiry) merupakan kegiatan inti dari CTL, memberikan penegasan bahwa pengetahuan dan keterampilan serta kemampuan-kemampuan lain yang diperlukan bukan merupakan hasil dari mengingat seperangkat fakta-fakta, tetapi merupakan hasil menemukan sendiri; (3) bertanya (questioning), melalui penerapan bertanya, pembelajaran akan lebih hidup, hasil pembelajaran yang lebih luas, mendalam, dan akan banyak ditemukan unsur-unsur terkait yang sebelumnya tidak terpikirkan baik oleh guru maupun siswa;
(4) masyarakat belajar (learning community) adalah membiasakan siswa untuk melakukan kerja sama dan memanfaatkan sumber belajar dari teman-teman belajarnya; (5) pemodelan (modelling) adalah proses pembelajaran dengan memperagakan sesuatu sebagi contoh yang dapat ditiru oleh siswa; (6) refleksi (reflection), adalah cara berpikir tentang apa yang baru terjadi atau baru saja dipelajari, dimana pada tahap refleksi, siswa diberi kesempatan untuk mencerna, menimbang, membandingkan, menghayati, dan melakukan diskusi dengan dirinya sendiri (learning to be); dan (7) penilaian, yaitu proses pengumpulan berbagai data dan informasi yang bisa memberikan gambaran atau petunjuk terhadap pengalaman belajar siswa.

Senada dengan pendapat beberapa ahli sebelumnya, Johnson (Alwasilah, 2010, p.19) berpendapat bahwa CTL bertujuan untuk menolong para siswa melihat makna di dalam materi akademik yang mereka pelajari dengan cara menghubungkan subjek-subjek akademik dengan konteks dalam kehidupan sehari-hari, yaitu dengan konteks keadaan pribadi, sosial, dan budaya mereka. Namun dijelaskan juga bahwa untuk mencapai tujuan ini, sistem tersebut meliputi delapan komponen yaitu membuat keterkaitan yang bermakna, melakukan pekerjaan yang berarti, melakukan pembelajaran yang diatur sendiri, melakukan kerja sama, berpikir kritis dan kreatif, membantu individu untuk tumbuh dan berkembang, mencapai standar yang tinggi, dan menggunakan penilaian yang autentik.

Strategi pembelajaran selanjutnya adalah pembelajaran open ended. Pembelajaran open ended adalah pembelajaran yang dimulai dengan pemberian masalah terbuka kepada siswa, untuk memberikan kesempatan memperoleh pengetahuan dan pengalaman menemukan, mengenali dan memecahkan masalah dengan berbagai teknik, agar siswa dapat menyelesaikan permasalahan dengan banyak jawaban benar. Feedman (Kwon et al, 2006, p.53) mengemukakan bahwa "open ended problem enable students to use high dimensional thingking skills by employing various writing methods". Feedman menyatakan bahwa open-ended memungkinkan siswa untuk menggunakan keterampilan berpikir dimensi tinggi dengan menggunakan berbagai metode penulisan. Sedangkan NCTM (1989, p.76) mengemukakan bahwa open ended sebagai "situation that allow students to experience problem with "messy" numbers or too much or not enough information or that have multiple 
solution, ech with different consequences". Tujuan pembelajaran open ended adalah siswa diharapkan dapat mengembangkan ide-ide kreatif dan pola pikir matematis, dengan diberikan masalah yang bersifat terbuka, siswa terlatih untuk me-lakukan investigasi berbagai strategi dalam menyelesaikan masalah. Dasar keterbukaan masalah diklasifikasikan dalam tiga tipe, yaitu (1) prosesnya terbuka, maksudnya memiliki banyak cara penyelesaian benar; (2) hasil akhirnya terbuka, maksudnya memiliki banyak jawaban benar; (3) cara pengembangan lanjutannya terbuka, maksudnya ketika siswa telah menyelesaikan masalahnya, mereka dapat mengembangkan masalah baru yaitu dengan cara merubah kondisi masalah sebelumnya.

Pendekatan open ended pada prinsipnya sama dengan pembelajaran berbasis masalah yaitu suatu pendekatan pembelajaran yang dalam prosesnya dimulai dengan memberi suatu permasalahan kepada siswa. Letak perbedaan antara kedua pendekatan tersebut, pada problem yang disajikan memiliki jawaban yang benar lebih dari satu. Problem yang memiliki jawaban benar lebih dari satu disebut problem tak lengkap atau problem open ended atau problem terbuka. Keunggulan pendekatan open ended yaitu, siswa mengambil bagian dalam kelas yang lebih aktif dan mengekspresikan ide-ide mereka lebih bebas, siswa dapat memiliki kesempatan lebih besar untuk menggunakan pengetahuan dan keterampilan matematika mereka lebih luas, semua siswa dapat menjawab masalah dalam cara yang berarti mereka sendiri, dan kelas dengan pembelajaran open ended memberikan para siswa berbagai pengalaman yang rasional. Selain mengembangkan aspek pengetahuan dan keterampilan, open ended juga terbukti efektif diterapkan dalam pembelajaran matematika ditinjau dari aspek afektif (Rahmawati \& Harta, 2014).

Terkait dengan permasalahan dan uraian tentang strategi pembelajaran tersebut, maka tujuan penelitian ini adalah untuk menemukan (1) pengaruh pembelajaran pada bangun ruang sisi lengkung dengan strategi pembelajaran kooperatif CTL dan Open Ended terhadap hasil belajar kognitif siswa, (2) pengaruh pembelajaran pada bangun ruang sisi lengkung dengan strategi pembelajaran kooperatif $C T L$ dan Open Ended terhadap sikap siswa, dan (3) pengaruh pembelajaran pada bangun ruang sisi lengkung dengan strategi pembelajaran kooperatif CTL dan Open Ended terhadap keterampilan matematika siswa.

\section{METODE}

Jenis penelitian ini adalah penelitian eksperimen semu (quasi eksperimental), dengan pendekatan kuantitatif. Desain penelitian ini dapat digambarkan sebagai berikut:

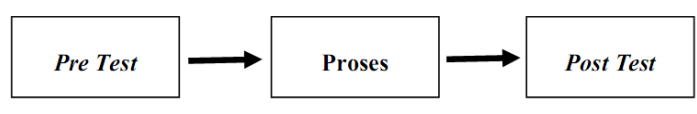

Gambar 1. Desain penelitian

Keterangan :

Pretest: Penilaian (kognitif, sikap, dan keterampilan) sebelum proses pelaksanaan pembelajaran

Proses: Proses Pembelajaran dengan stategi Contextual Teaching and Learning teaching (CTL) \& open ended.

Posttest: Penilaian (kognitif, sikap, dan keterampilan) setelah proses pelaksanaan pembelajaran

Populasi dalam penelitian ini adalah siswa kelas IX SMP Muhammadiyah 8 Yogyakarta tahun pelajaran 2014/2015, yang terdiri atas 5 kelas, dengan jumlah siswa keseluruhan 148 siswa.

Pengambilan data, diambil dari sampel penelitian yaitu siswa kelas IX D yang berjumlah 30 siswa yang dipilih secara acak dari kelima kelas IX di sekolah tersebut. Kelas IX D diberi perlakuan dengan kegiatan pembelajaran melalui strategi Contextual Teaching and Learning dan Open Ended. Teknik pengumpulan data untuk mengukur kognitif, sikap dan keterampilan matematis siswa dilakukan dalam berbagai tahap, yaitu (1) menyusun instrumen penelitian, kemudian diuji validasi; (2) memberikan pretes di kelas untuk mengetahui data awal tingkat kognitif siswa; (3) melakukan observasi (oleh pihak observer) selama kegiatan pembelajaran berlangsung, untuk mengetahui sikap siswa; (4) melakukan postes diakhir kegiatan pembelajaran untuk mengetahui pengaruh strategi yang diberikan dari aspek kognitif (pengetahuan) siswa; (5) memberikan angket untuk mengetahui sikap matematis siswa; (6) memberikan tugas individu yang dikerjakan di rumah untuk mengetahui keterampilan siswa.

Instrumen pengumpulan data yang digunakan dalam penelitian ini adalah tes. Tes yang digunakan dalam penelitian berupa tes uraian (sifatnya terbuka). Menurut Kusaeri \& Suprananto (2012, p.136) soal bentuk uraian merupakan suatu soal yang jawabannya menuntut siswa mengingat dan mengorganisasikan gagasan-gagasan atau hal-hal yang telah dipelajarinya dengan cara mengemukakan atau mengekspresikan gagasan tersebut dalam bentuk uraian tertulis. Selain itu, tes uraian harus dijawab 
dengan urutan prosedural, dengan langkahlangkah tertentu, baik langkah-langkah orang lain, mengembangkan langkah sendiri, mengevaluasi, atau mengurangi langkah tertentu.

Teknik analisis data meliputi analisis deskriptif dan inferensial. Data yang dianalisis dalam penelitian ini meliputi skor hasil belajar kognitif, sikap, dan keterampilan siswa. Strategi pembelajaran kooperatif Contextual Teaching Learning dan Open Ended dianggap memiliki pengaruh terhadap hasil belajar kognitif, sikap, dan keterampilan siswa, jika hasil posttest menunjukkan perbedaan yang signifikan dibandingkan dengan hasil pretest, dan rata-rata hasil posttest lebih tinggi dibandingkan dengan hasil pretest. Pengujian hipotesis dilakukan dengan menggunakan paired-samples $t$ test.

\section{HASIL DAN PEMBAHASAN}

Data yang diperoleh kemudian dideskripsikan. Data yang dideskripsikan berupa hasil pretest dan posttest hasil belajar kognitif, sikap dan keterampilan siswa yang dikumpulkan sebelum dan sesudah diberi perlakuan. Data pretest dan posttest hasil belajar kognitif disajikan pada Tabel 1.

Tabel 1. Data Pretest dan Posttest Hasil Belajar Kognitif

\begin{tabular}{ccc}
\hline Deskripsi & Pretest & Posttest \\
\hline Minimum & 2,00 & 4,5 \\
Minimum ideal & 0,00 & 0,00 \\
Maksimum & 2,95 & 8,5 \\
Maksimum ideal & 10,0 & 10,0 \\
Range & 0,95 & 4,0 \\
Mean & 2,3353 & 7,017 \\
Standar Deviasi & 0,2577 & 1,0042 \\
\hline
\end{tabular}

Berdasarkan Tabel 1, diketahui bahwa nilai rata-rata pretest kemampuan kognitif yaitu 2,34 sedangkan posttest 7,02.

Tabel 2. Data Pretest dan Posttest Hasil Belajar Sikap

\begin{tabular}{ccc}
\hline Deskripsi & Pretest & Posttest \\
\hline Minimum & 2,00 & 2,58 \\
Minimum ideal & 1,00 & 1,00 \\
Maksimum & 2,95 & 3,25 \\
Maksimum ideal & 4,00 & 4,00 \\
Range & 0,95 & 0,67 \\
Mean & 2,3353 & 2,9433 \\
Standar Deviasi & 0,2576 & 0,1807 \\
\hline
\end{tabular}

Berdasarkan Tabel 2, diketahui bahwa nilai rata-rata pretest untuk sikap yaitu 2,33 sedangkan posttest 2,94
Tabel 3. Data Pretest dan Posttest Hasil Belajar Keterampilan

\begin{tabular}{ccc}
\hline Deskripsi & Pretest & Posttest \\
\hline Minimum & 3,50 & 5,5 \\
Minimum ideal & 0,00 & 0,00 \\
Maksimum & 7,00 & 8,5 \\
Maksimum Ideal & 10,00 & 10,00 \\
Range & 3,50 & 3,0 \\
Mean & 5,2500 & 7,2167 \\
Standar Deviasi & 0,9891 & 0,86785 \\
\hline
\end{tabular}

Berdasarkan Tabel 3, diketahui bahwa nilai rata-rata pretest untuk keterampilan yaitu 5,25 sedangkan posttest 7,22.

Tabel 4. Hasil Uji Normalitas

\begin{tabular}{cc}
\hline Data & p (sig) \\
\hline Pretest Kognitif & 0,24 \\
Posttest Kognitif & 0,50 \\
Pretest Sikap & 0,24 \\
Posttest Sikap & 0,65 \\
Pretest Keterampilan & 0,38 \\
Posttest Keterampilan & 0,65 \\
\hline
\end{tabular}

Berdasarkan Tabel 4, diperoleh nilai signifikansi $(p)$ masing-masing variabel $>0.05$, sehingga dapat disimpulkan bahwa distribusi keenam data tersebut dinyatakan normal, sehingga layak untuk dilakukan analisis dengan statistik parametrik.

Tabel 6. Hasil Uji Perbedaan Hasil Belajar Kognitif (Pretest dan Posttest)

\begin{tabular}{cccc}
\hline & $\mathbf{t}_{\text {hitung }}$ & Sig & $\begin{array}{c}\boldsymbol{t}_{\text {tabel }} \\
(\boldsymbol{\alpha}=\mathbf{0 , 0 5})\end{array}$ \\
\hline Kognitif & 11,145 & 0,000 & 2,0452 \\
\hline
\end{tabular}

Berdasarkan hasil perhitungan diperoleh harga $t_{\text {hitung }}=11,145$ dengan sig $=0,000$. Nilai $\mathrm{t}_{\text {tabel }}$ pada $(\mathrm{df}=29 ; \alpha=5 \%)$ adalah 2,05. Karena nilai $t_{\text {hitung }}>t_{\text {tabel }}(11,145>2,045)$ berarti Ho ditolak dan Ha diterima.

Tabel 7. Hasil Uji Perbedaan Sikap (Pretest dan Posttest)

\begin{tabular}{cccc}
\hline & $\mathbf{t}_{\text {hitung }}$ & Sig & $\begin{array}{c}\boldsymbol{t}_{\text {tabel }} \\
(\boldsymbol{\alpha}=\mathbf{0 , 0 5})\end{array}$ \\
\hline Sikap & 10,498 & 0,000 & 2,0452 \\
\hline
\end{tabular}

Berdasarkan hasil perhitungan diperoleh harga $t_{\text {hitung }}=10,1498$ dengan sig $=0,000$. Nilai $t_{\text {tabel }}$ pada $(\mathrm{df}=29 ; \alpha=5 \%)$ adalah 2,04. Karena nilai $t_{\text {hitung }}>t_{\text {tabel }}(10,498>2,0452)$ berarti Ho ditolak dan Ha diterima. 
Tabel 8. Hasil Uji Perbedaan Keterampilan (Pretest dan Posttest)

\begin{tabular}{cccc}
\hline & $\mathbf{t}_{\text {hitung }}$ & Sig & $\begin{array}{c}\boldsymbol{t}_{\text {tabel }} \\
(\boldsymbol{\alpha}=\mathbf{0 , 0 5})\end{array}$ \\
\hline Keterampilan & 14,750 & 0,000 & 2,0452 \\
\hline
\end{tabular}

Berdasarkan hasil perhitungan diperoleh harga $t_{\text {hitung }}=14,750$ dengan sig $=0,000$. Nilai $\mathrm{t}_{\text {tabel }}$ pada $(\mathrm{df}=29 ; \alpha=5 \%)$ adalah 2,0452 . Karena nilai $t_{\text {hitung }}>t_{\text {tabel }}(14,750>2,0452)$ berarti Ho ditolak dan Ha diterima.

Hasil analisis menunjukkan bahwa terdapat pengaruh pembelajaran pada bangun ruang sisi lengkung dengan strategi pem-belajaran kooperatif Contextual Teaching Learning dan Open Ended terhadap hasil belajar kognitif siswa. Hasil belajar kognitif meningkat dari ratarata 5,13 menjadi 7,01 setelah pembelajaran dengan strategi pembelajaran kooperatif Contextual Teaching Learning dan Open Ended. Hal ini sesuai dengan fungsi mata pelajaran matematika sebagai sarana mengembangkan penalaran dengan menggambarkan bilangan-bilangan dan simbol-simbol serta ketajaman penalaran yang dapat memberi kejelasan dan menyelesaikan permasalahan dalam kehidupan sehari-hari. Dalam pembelajaran matematika, proses belajar mengharuskan siswa pada posisi aktif (Hamalik, 2008, p.28).

Sejalan dengan pemikiran Kwon et al (2006, p.53), "open ended problem can give student a sense of achievment and fulfillment because it is possible even for student with less matematical ability to set forth their own solutions within their own ability. Furthe-rmore, it offers students a chance to feel what it is to be real mathematics learner in the course of creating their own problems. Here, what is significant is that both teachers and students recognize the learner's contribution in all learning processes and that every learner has confidence in their ability to find their own answer". Open ended dapat memberikan siswa rasa beprestasi dan pemenuhan karena bahkan untuk siswa dengan kemampuan matematical kurang juga dapat menetapkan solusi mereka sendiri dengan kemampuan mereka sendiri. Selanjutnya, ia menawarkan siswa kesempatan untuk merasakan apa itu menjadi pembelajar matematika nyata dalam perjalanan menyelesaikan masalah mereka sendiri. Di sini, apa yang penting adalah bahwa baik guru dan siswa mengakui kontribusi pembelajar dalam semua proses belajar dan bahwa setiap peserta didik memiliki kepercayaan diri dalam kemampuan mereka untuk menemukan jawaban mereka sendiri.

Aspek kognitif berorientasi pada kemampuan berpikir yang mencakup kemampuan intelektual yang lebih sederhana, yaitu mengingat, sampai pada kemampuan memecahkan masalah yang menuntut siswa untuk menghubungkan dan menggabungkan ide-ide, gagasan, metode atau prosedur yang dipelajari untuk memecahkan masalah tersebut. Dengan demikian aspek kognitif adalah subtaksonomi yang mengungkapkan tentang kegiatan mental yang sering berawal dari tingkat pengetahuan sampai ketingkat yang paling tinggi yaitu evaluasi. Hal ini sesuai juga dengan konsep pembelajaran dan pengajaran kontekstual melibatkan siswa dalam aktivitas penting yang membantu mereka mengaitkan pelajaran akademis dengan konteks kehidupan nyata yang mereka hadapi. Ketika mereka melakukan aktivitas belajar, maka mereka mengaitkan isi aktivitas dengan konteks dalam situasi kehidupan, dan dengan cara ini mereka menemukan makna. Ini juga sesuai dengan konsep yang dikemukakan oleh Johnson (2002, p.17), bahwa sebuah sistem yang merangsang otak untuk menyusun pola-pola yang mewujudkan makna, dan mendefinisikan CTL sebagai suatu sistem pengajaran yang cocok dengan otak karena menghasilkan makna dengan menghubungkan muatan akademis dengan konteks dari kehidupan sehari-hari siswa.

Hasil penelitian ini sesuai dengan penelitian yang dilakukan oleh Rohayati (2010) tentang "Pengembangan Bahan Ajar dengan Pendekatan Open Ended untuk Menintgkatkan Kemampuan berpikir kritis, Kreatif, dan Reflektif siswa SMA", dengan kesimpulan bahwa: (1) peningkatan kemampuan komunikasi matematik siswa yang mengikuti pembelajaran dengan menggunakan pendekatan open-ended lebih meningkat daripada siswa yang mengikuti pembelajaran matematika dengan model ekspositori; (2) terdapat peningkatan kemampuan berpikir reflektif terhadap siswa yang memperoleh pembelajaran matematika dengan menggunakan pendekatan Open-Ended melalui model pembelajaran kooperatif; (3) peningkatan kemampuan berpikir kreatif siswa yang mendapatkan pembelajaran pemecahan masalah matematis terbuka (open-ended) lebih baik secara berarti dibandingkan dengan siswa yang mendapatkan pembelajaran ekspositori; (4) respon siswa terhadap pembelajaran matematika dengan pendekatan open-ended positif. 
Penelitian lain yang juga senada dengan hasil penelitian ini adalah penelitian yang yang berjudul "Pendekatan Open-Ended dalam Pembelajaran Matematika" oleh Aras dkk (2013). Dalam penelitian tersebut disimpulkan bahwa pendekatan open-ended adalah pendekatan yang melibatkan siswa dalam masalah terbuka yang diformulasikan untuk memiliki beberapa jawaban yang benar "tidak lengkap" atau "terbuka". Masalah terbuka dianggap sebagai masalah yang multi-solusi, karena rumusan masalahnya tidak jelas. Pendekatan open-ended dianggap sebagai assessment aproach, dengan meningkatkan kualitas pembelajaran siswa, karena dapat meningkatkan kreativitas belajar siswa yang beragam dan dapat membantu guru mengeksplorasi kemampuan siswa.

Hasil penelitian ini menguatkan konsep bahwa strategi CTL dan Open Ended terbukti berpengaruh pada peningkatan hasil belajar kognitif siswa. Menjadi makin jelas bahwa pengetahuan tidak hanya berupa seperangkat fakta dan konsep belaka. Manusia sendiri yang membangun, dan membuat pengetahuan itu menjadi bermakna. Oleh karena itu, dalam kaitannya dengan pembelajaran kontekstual, seorang guru harus mampu menciptakan desain pembelajaran yang berhubungan erat dengan kehidupan nyata siswa. Peran guru disini adalah memfasilitasi siswa agar infor-masi yang diperolehnya menjadi bermakna, dan memberi kesempatan kepada siswa untuk menemukan dan menerapkan ide mereka, serta menyadarkan mereka untuk menerapkan ide yang dicetuskan tersebut dalam situasi nyata.

Tujuan penelitian selanjutnya yang ingin diketahui dengan dilaksanakannya penelitian ini adalah pengaruh stategi CTL dan Open -Ended terhadap sikap siswa. Berdasarkan hasil penelitian dapat diketahui bahwa terdapat pengaruh pembelajaran pada bangun ruang sisi lengkung dengan strategi pembelajaran kooperatif Contextual Teaching Learning dan Open Ended terhadap sikap siswa. Sikap siswa dalam mengikuti pelajaran bangun ruang sisi lengkung meningkat dari rata-rata 2,33 menjadi 2,94 setelah pembelajaran dengan strategi pembelajaran kooperatif Contextual Teaching Learning dan Open Ended. Dilihat dari skor juga terlihat bahwa $73 \%$ kategori cukup dan $27 \%$ kategori baik sebelum eksperimen, menjadi 100\% kategori baik setelah pembelajaran dengan strategi pembelajaran kooperatif Contextual Teaching Learning dan Open Ended. Hal ini sesuai dengan karakteristik dari strategi pembelajaran kontekstual yang memiliki tujuh komponen utama yaitu konstruktivisme (contructivism), menemukan (inquiri) bertanya (questioning), masyarakat belajar (learning community), pemodelan (modeling), refleksi (reflection), dan penilaian yang sebenarnya (authentic assessment).

Mendukung uraian tersebut, Howey \& Keneth (Rusman, 2014) menyatakan bahwa Contextual Teaching Learning merupakan pembelajaran yang memungkinkan terjadinya proses belajar di mana siswa menggunakan pemahaman dan kemampuan akademiknya dalam berbagai konteks dalam dan luar sekolah untuk memecahkan masalah yang bersifat simulatif ataupun nyata, baik sendiri-sendiri maupun bersamasama. Strategi Contextual Teaching Learning dan open ended menjadikan pembelajaran matematika menjadi menyenangkan. Proses yang melibatkan secara aktif siswa, menjadikan siswa akan dapat belajar dengan baik, karena dalam pembe-lajaran matematika, proses belajar mengharuskan siswa pada posisi aktif (Hamalik, 2008, p.4). Dengan demikian maka hasil penelitian ini menguatkan konsep bahwa strategi pembelajaran kooperatif Contextual Teaching Learning dan Open Ended memberikan pengaruh nyata terhadap sikap siswa dalam proses pembelajaran.

Tujuan penelitian yang terakhir yaitu untuk mengetahui pengaruh Stategi CTL dan Open Ended terhadap keterampilan siswa. Berdasarkan hasil perhitungan dapat diketahui bahwa terdapat pengaruh pembelajaran pada bangun ruang sisi lengkung dengan strategi pembelajaran kooperatif Contextual Teaching Learning dan Open Ended terhadap keterampilan siswa. Keterampilan siswa dalam menyelesaikan soal bangun ruang sisi lengkung meningkat dari ratarata 5,25 menjadi 7,21 setelah pembelajaran dengan strategi pembelajaran kooperatif Contextual Teaching Learning dan Open Ended.

Hasil tersebut sesuai dengan pendapat Feedman (Kwon et al, 2006, p.53) "stated that open ended problem enable students to use high dimensional thingking skills by employing various writing methods." Feedman menyatakan bahwa open-ended memungkinkan siswa untuk menggunakan keterampilan berfikir dimensi tinggi dengan menggunakan berbagai metode penulisan. Pendekatan pembelajaran open-ended merupakan pendekatan pembelajaran yang dimulai dari mengenalkan atau menghadapkan permasalahan terbuka pada siswa. Selanjutnya dengan menggunakan banyak jawaban yang benar dari masalah yang diberikan akan memberi- 
kan pengalaman pada siswa dalam menemukan sesuatu yang baru selama pembelajaran. Harapannya melalui kegiatan pembelajaran tersebut siswa dapat menyelesaikan permasalahan dengan banyak cara.

Sejalan dengan hal tersebut, menurut NCTM (1989, p.76) menjelaskan bahwa open ended sebagai situasi yang membiarkan siswa untuk mengalami masalah dengan angka-angka yang tidak beraturan, angka-angka yang banyak, informasi yang tidak lengkap, atau mempunyai solusi ganda, masing-masing dengan konsekuensi yang berbeda. Sedangkan dasar keterbukaan masalah diklasifikasikan dalam tiga tipe. Pertama prosesnya terbuka, maksudnya memiliki banyak cara penyelesaian benar, kedua hasil akhirnya terbuka, maksudnya memiliki banyak jawaban benar, ketiga cara pengembangan lanjutannya terbuka, maksud-nya ketika siswa telah menyelesaikan masalah, mereka dapat mengembangkan masalah baru yaitu dengan cara merubah kondisi masalah sebelumnya.

Dalam proses pembelajaran open ended, jelas sekali bahwa keterampilan siswa diasah untuk menyelesaikan soal-soal matematika. Hal ini juga sesuai dengan pendapat yang dikemukakan Sawada (Becker \& Shimada, 1997, p.27), bahwa dalam pembelajaran open ended (1) siswa akan belajar bagaimana menemukan hubungan. Soal ini diberikan bertujuan agar siswa dapat menemukan beberapa aturan atau hubungan matematis; (2) siswa dapat mengklasifikasi berdasarkan karakteristik yang berbeda dari suatu objek tertentu untuk memformulasikan beberapa konsep tertentu; (3) siswa dapat melakukan pengukuran. Siswa diminta menentukan ukuran-ukuran numerik dari suatu kejadian tertentu. Siswa diharapkan dapat mengaplikasikan pengetahuan dan keterampilan yang telah dipelajari sebelumnya untuk memecahkan masalah.

Berdasarkan uraian diatas maka strategi Contextual Teaching Learning dan open ended dalam pembelajaran matematika terbukti berpengaruh pada meningkatnya keteramapilan siswa dalam menyelesaikan soal matematika. Siswa dapat mengembangkan ide-ide kreatif dan pola pikir matematis, dengan diberikan masalah yang bersifat terbuka, siswa terlatih untuk melakukan investigasi berbagai strategi dalam menyelesaikan masalah. Siswa akan memahami bahwa proses penyelesaian suatu masalah sama pentingnya dengan hasil akhir yang diperoleh.

\section{SIMPULAN DAN SARAN}

\section{Simpulan}

Berdasarkan hasil analisis dan pembahasan yang dilakukan, maka dapat disimpulkan bahwa (1) terdapat pengaruh pembelajaran pada bangun ruang sisi lengkung dengan strategi pembelajaran kooperatif Contextual Teaching Learning dan Open Ended terhadap hasil belajar kognitif siswa; (2) terdapat pengaruh pembelajaran pada bangun ruang sisi lengkung dengan strategi pembelajaran kooperatif Contextual Teaching Learning dan Open Ended terhadap sikap siswa; dan (3) terdapat pengaruh pembelajaran pada bangun ruang sisi lengkung dengan strategi pembelajaran kooperatif Contextual Teaching Learning dan Open Ended terhadap keterampilan siswa.

\section{Saran}

Beberapa saran yang dapat dikemukakan oleh peneliti adalah (1) guru matematika hendaknya menggunakan strategi pembelajaran kooperatif Contextual Teaching Learning dan Open Ended dalam pembelajaran di kelas, karena terbukti strategi tersebut memberi pengaruh pada hasil belajar kognitif siswa, sikap dan keterampilan siswa. Strategi CTL dan Open Ended juga membuat siswa lebih aktif, dapat merespon masalah matematika dan termotivasi untuk memberikan bukti dan penjelasan; (2) peneliti selanjutnya hendaknya dapat menggunakan penelitian ini sebagai bahan pertimbangan untuk penelitian selanjutnya mengenai berbagai strategi pembelajaran dan dalam kompetensi dasar yang lain.

\section{DAFTAR PUSTAKA}

Alwasilah, C. (2011). CTL Contextual teaching and learning. Bandung: Kaifa Learning.

Ambrose et.al. (2010). How learning works. 7 research-based principles for smart teaching. San Fransisco, CA: JosseyBass.

Aras, I., Ardiny, V., Djafar, S.. (2013). Pendekatan open-ended dalam pembelajaran matematika. Tesis tidak diterbitkan. Universitas Negeri Makassar.

Arend, R. I., \& Kilcher, A. (2010). Teaching for student learning: Becoming an accomplished teacher. New York, NY: Routledge. 
Becker, J. P., \& Shimada, S. (1997). The openended approach: A new proposal for teaching mathematics. Reston, VA: NCTM.

Hamalik, O. (2008). Kurikulum dan pembelajaran. Jakarta: Bumi Aksara.

Johnson, E. B. (2002). Contextual teaching learning: Why it is and why it is here to stay. Thousand Oaks, CA: Sage Publication Ltd.

Kusaeri \& Suprananto. (2012). Pengukuran dan penilaian pendidikan. Yogyakarta: Graha Ilmu.

Kwon, O. N, Park, J. S \& Park, J. H. (2006). Cultivating divergent thingking in mathematics through an open-ended approach. Asia Pacific Education Review, 7(1), 51-61.

Majid, A. (2014). Pembelajaran tematik terpadu. Bandung: PT Remaja Rosdakarya.

NCTM. (1989). Curriculum and evaluation standard for school mathematics. Reston, VA: NCTM.

Nitko, A. J. \& Brookhart, S. M. (2007). Educational assesment of students. Upper Saddle River, NJ: Pearson Education.

Presiden Republik Indonesia. (2003). Peraturan Pemerintah RI Nomor 20, Tahun 2003, tentang Sistem Pendidikan Indonesia.
Putri, R., \& Abadi, A. (2014). Keefektifan pembelajaran matematika dengan pendekatan CTL dan problem posing ditinjau dari ketercapaian $\mathrm{SK} / \mathrm{KD}$ dan kemampuan koneksi matematik. PYTHAGORAS: Jurnal Pendidikan Matematika, $\quad 9(1), \quad$ 79-89. doi:http://dx.doi.org/10.21831/pg.v9i1.90 70

Rahmawati ES, Y., \& Harta, I. (2014). Keefektifan pendekatan open-ended dan CTL ditinjau dari hasil belajar kognitif dan afektif. Jurnal Riset Pendidikan Matematika, $\quad 1(1), \quad$ 113-126. doi:http://dx.doi.org/10.21831/jrpm.v1i1. 2669

Rohayati, A. (2010). Pengembangan bahan ajar dengan pendekatan open ended untuk meningkatkan kemampuan berpikir kritis, kreatif, dan reflektif siswa SMA. Tesis tidak diterbitkan. Universitas Pendidikan Indonesia.

Rusman. (2014). Model-model pembelajaran: Mengembangkan profesional guru. Jakarta: Raja Grafindo Persada.

Widoyoko, E. P. (2014). Penilaian hasil pembelajaran di Sekolah. Yogyakarta: Pustaka Pelajar.

Zan, R. \& Martino, P. D. (2007). Attitude Toward Matematics: Overcoming The Positivel Negative Dichotomy. TTME Monograph3, pp.157-168. 